\title{
Redescription of Centropages ponticus Karavaev, 1895 (Copepoda: Calanoida) from the Black Sea
}

\section{Переописание Centropages ponticus Karavaev, 1895 (Copepoda: Calanoida) из Черного моря}

\author{
I.Yu. Prusova, E.A. Galagovets, E.V. Popova \\ И.Ю. Прусова, Е.А. Галаговец, Е.В. Попова
}

Kovalevsky Institute of Marine Biological Research, Russian Academy of Sciences, 2 Nakhimov Ave., 299011 Sevastopol, Russian Federation. E-mails: iprusova@gmail.com; didobe@mail.ru; el-popova@yandex.ru

Институт морских биологических исследований им. А.О. Ковалевского РАН, Пр. Нахимова, 2, 299011 Севастополь, Россия.

KEY WORDS: Centropages ponticus, Calanoida, Copepoda, redescription, Black Sea, Mediterranean Sea.

КЛЮЧЕВЫЕ СЛОВА: Centropages ponticus, Calanoida, Copepoda, переописание, Черное море, Средиземное море.

ABSTRACT. Centropages ponticus Karavaev, 1895 is an endemic to the Mediterranean basin and one of the common species of copepods in the coastal waters of the region. However, its first description is very short and incomplete, and as a consequence, some uncertainty in the issue of correct identification of this species still remains. In the present work, a complete illustrated description of $C$. ponticus from the Sevastopol Bay (Black Sea), a type locality of this species, is performed. Based on a comparative analysis of five species of the hamatus group of the genus Centropages including $C$. ponticus, a differential diagnosis of the latter is given. Differences in the morphological structure of $C$. ponticus from the Black (own data) and Mediterranean (literature data) seas are described.

How to cite this article: Prusova I.Yu., Galagovets E.A., Popova E.V. 2019. Redescription of Centropages ponticus Karavaev, 1895 (Copepoda: Calanoida) from the Black Sea // Arthropoda Selecta. Vol.28. No.4. P.515-528. doi: 10.15298/arthsel. 28.4.04

РЕЗЮМЕ. Centropages ponticus Karavaev, 1895 - эндемик Средиземноморского бассейна и один из обычных массовых видов копепод в прибрежных акваториях данного региона. Однако первое описание этого вида очень короткое и неполное, вследствие чего имеются трудности при его идентификации. В настоящей работе выполнено полное иллюстрированное описание $C$. ponticus из Севастопольской бухты (Черное море), типового местообитания этого вида. На основе сравнительного анализа пяти видов группы hamatus рода Centropages, куда входит и C. ponticus, дан его дифференциальный диагноз. Охарактеризованы различия в морфологическом строении C. ponticus из Черного (собственные данные) и Средиземного (литературные данные) морей.

\section{Introduction}

Centropages ponticus Karavaev, 1895 is one of the common and abundant copepod species in the coastal areas of the Mediterranean basin [Greze et al., 1971; Gubanova et al., 2014; Papantoniou et al., 2015; Siokou-Frangou et al., 2004; Soler et al., 1988; Ustun et al., 2018; and others]. This species was originally described by V. Karavaev [1895], who, studying the Black Sea copepods, revealed differences in the structure of the male fifth leg between the local Centropages and $C$. kroyeri Giesbrecht, 1893 (the species described two years earlier from the Mediterranean Sea), and recorded the Black Sea individuals as Centropages kroyeri var. pontica. Three decades later, Gurney [1927] found in the Suez Canal one male specimen identical to that described by Karavaev, and asserted the morphological differences between C. kroyeri var. pontica and $C$. kroyeri to be significant enough to regard this variety as a separate species, C. ponticus Karavaev, 1895. Later on, Kovalev [1967] conducted a comparative morphological analysis of $C$. ponticus and C. kroyeri based on the material collected in the Mediterranean Sea at the stations where both these species were present in plankton. This author reported $C$. ponticus to be occurring abundantly at the North African coast and in the Adriatic Sea along with C. kroyeri, as well as he described in detail morphological differences between these two species in males and also in females, and confirmed the conclusion made by Gurney [1927] concerning specific level of C. ponticus [Kovalev, 1967]. Karavaev [1895] noted that he had found C. kroyeri var. pontica in Sevastopol Bay and in the southeastern part of the Black Sea, so these localities can be considered as the type ones for this species.

To date, $C$. ponticus has been recorded for the Mediterranean basin only [Kovalev, 1967; Matishov et al., 2015; Razouls et al., 2005-2019]. C. ponticus is 
reported to be an opportunistic and euryhaline species [Soler et al., 1988, and references therein] exhibiting variability in size related to environmental changes [Kovalev, 1967; Soler et al., 1988]. Morphological variability of $C$. ponticus and resulting difficulty in the correct identification of this species were also repeatedly noted [Garcia-Rodriguez, 1985; Soler et al., 1988; Kršinić, 2017]. Karavaev's [1895] description of $C$. ponticus, unfortunately, is short and incomplete with only body, rostrum and fifth legs of the female, and fourth and fifth legs of the male figured and described. The lack of detailed descriptions and drawings of $C$. ponticus caused the need to revise morphology of this species, and at least in two studies, re-descriptions have been made: on the basis of specimens from the Cullera Bay, western Mediterranean [Soler et al., 1988], and from the saline lake Mir, eastern Adriatic [Kršinić, 2017].

To our knowledge, no morphological analysis resulting in a detailed characterization and re-description of $C$. ponticus from the Black Sea was carried out, thus, some uncertainty in the issue of a correct identification of this species still remains.

Our objective was to re-describe and illustrate, in detail, the female and male of Centropages ponticus Karavaev 1895 from the samples collected in Sevastopol Bay, the place of this species type locality.

\section{Material and methods}

The examined specimens were sorted from formaldehyde preserved samples collected with a Juday net $\left(0.1 \mathrm{~m}^{2}\right.$ mouth area and $150 \mu$ mesh size $)$ in Sevastopol Bay $\left(44.621700^{\circ} \mathrm{N}, 33.549950^{\circ} \mathrm{E}\right)$ on August 29, 2013 , in the layer $0-10 \mathrm{~m}$ at a sea surface temperature $25^{\circ} \mathrm{C}$. Entire specimens and dissected parts were mounted in a 50:50 solution of glycerine and distilled water. Measurements were made with the use of a LOMO MBR-9 stereomicroscope. The length of the whole body (TL) was measured laterally from the tip of cephalosome to the posterior margin of the caudal ramus (excluding setae). All line drawings were made using a camera lucida on a Leica DM LS2 compound microscope and 'inked' digitally [Coleman, 2003]. Voucher specimens of $C$. ponticus ( 10 females and 10 males) are deposited in the collection of the Institute of Marine Biological Research of RAS, Sevastopol, Russia. The system of morphological nomenclature is based on that of Huys \& Boxshall [1991]. Articulating segments of the antennules and mouthparts are designated by Arabic numerals, ancestral segments and setae by Roman numerals. One seta and one aesthetasc on a segment of the antennule are designated: $1 \mathrm{~s}+1 \mathrm{a}$. Setal formulae are given in sequence from proximal to distal.

The following abbreviations are used in the tables: CR caudal rami; Enp - endopod; EnpI-III - endopod ancestral segments 1-3; Exp - exopod; ExpI-III - exopod ancestral segments 1-3; Gns - genital somite; P1-5 swimming legs $1-5$; $\mathrm{Pd} 5$ - pedigerous somite 5 ; $\mathrm{Pr}$ prosome; TL — total body length; $\mathrm{Ur}$ - urosome; $\mathrm{n} / \mathrm{d}$ - no data.

\section{Taxonomy}

Order CALANIDAE Dana, 1846

Genus Centropages Krøyer, 1849

Centropages ponticus Karavaev, 1895

Figs 1-7.

Centropages krøyeri var. pontica Karavaev, 1895, Table I, figs 16-19, Table II, fig. 1.

Centropages krøyeri: Razouls, 1972, fig. 47, B.

Female. Total length 1.07-1.22 mm (mean 1.15 $\mathrm{mm}, \mathrm{n}=34$ ). Body robust, prosome about 2.5 times as long as urosome. Cephalosome and first pedigerous somite, fourth and fifth pedigerous somites separate; the latter symmetrical with two conspicuous, caudally produced posterolateral projections (Figs 1a, 7a). Rostrum extends into two long, thin filaments directed postero-ventrally. Urosome of three free somites. Genital double-somite is the biggest, asymmetrical in dorsal view, widest at its posterior one-half, swollen more conspicuously on the right, with both left and right lateral swellings covered with small spinules (Figs 1fi, 7a), dorsal surface of the somite flat, without spinules (Fig. 7b); genital area postero-ventral, genital operculum large, located ventrolaterally on left side occupying about $1 / 3$ of the widest width of genital doublesomite, triangular in shape and with a slightly curved distal margin (Fig. 1i); left ventrolateral edge of genital double-somite with a rounded protrusion (arrowed in Fig. 1g,i) better noticeable when genital operculum adjoins the somite not tightly. Caudal rami symmetrical, slightly dilated posteriorly, approximately three times as long as wide, with six terminal setae and small setules in the inner border; ancestral seta I absent, seta VII inserted immediately anterior to seta VI; seta V longest being approximately as long as urosome including caudal rami, seta VII shortest (Fig. 1a,f).

Antennule (Fig. 1b,d,e): symmetrical, extending to a posterior border of caudal rami, of 24 articulated segments; ancestral segments II-IV completely fused; armature as follows: I-2s + 1a, II-IV-3s + 1a, V-1s + 1a, VI-2s + 1a, VII-2s + 1a, VIII-1s + 1a, IX-2s+1a, $\mathrm{X}-2 \mathrm{~s}+1 \mathrm{a}$ (distalmost seta modified - short and curved), XI to XXI-2s + 1a, XXII-1s, XXIII-1s, XXIV-1s + $1 \mathrm{~s}$, XXV-1s + 1s, XXVI-XXVIII-5s + 1a.

Antenna (Fig. 2a): coxa with one long inner seta; basis with two long inner setae; endopod two-segmented: segment 1 with two inner setae, segment 2 bilobed with nine and seven setae on proximal and distal lobes, respectively, distal lobe armed with row of spinules; exopod with ancestral segments I-II and III-IV fused, fusion line between segments III and IV visible; ancestral segments I-VIII each with long plumose seta, terminal segments IX-X with $1+3$ setae.

Mandible (Fig. 2b,c): gnathobase with eight teeth and one seta, third and fourth teeth with small spinules at their base; mandibular palp basis with four setae; endopod two-segmented with four and nine setae, respectively; exopod five-segmented with 1, 1, 1, 1, 2 setae. 


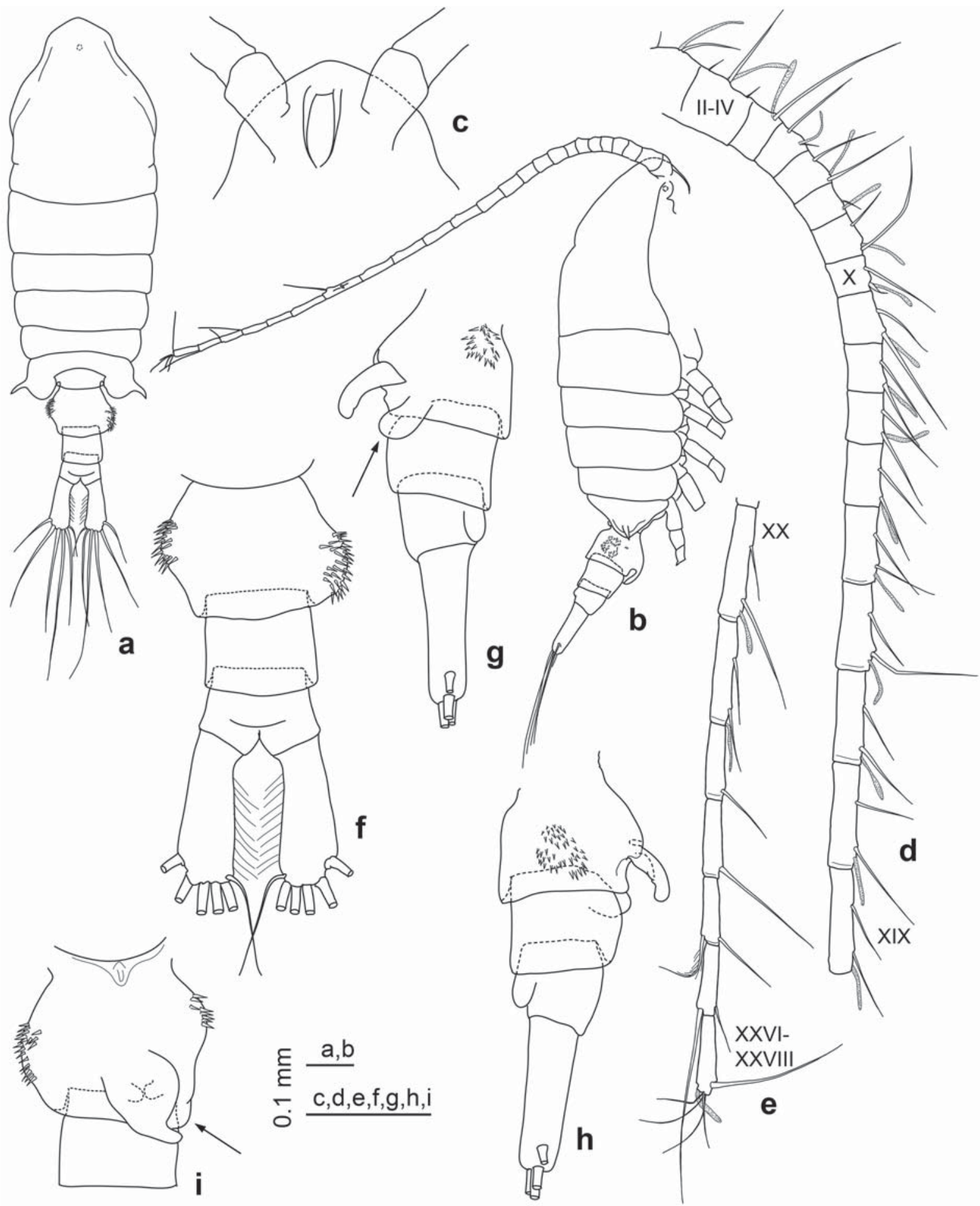

Fig. 1. Centropages ponticus female: a - dorsal view; b - lateral view; c - anterior head, ventral view; d - antennule, segments IXIX; e - antennule, segments XX-XXVIII; f - urosome, dorsal view; g — urosome, left lateral view; h — urosome, right lateral view; $\mathrm{i}$ genital double-somite, ventral view.

Рис. 1. Centropages ponticus, самка: a - вид со спинной стороны; b - вид сбоку; с - верхняя часть головы, вид с брюшной стороны; d - антеннула, членики I-XIX; е - антеннула, членики XX-XXVIII; f - уросома, вид со спинной стороны; g уросома, вид сбоку слева; $\mathrm{h}$ - уросома, вид сбоку справа; i — генитальный членик, вид с брюшной стороны. 


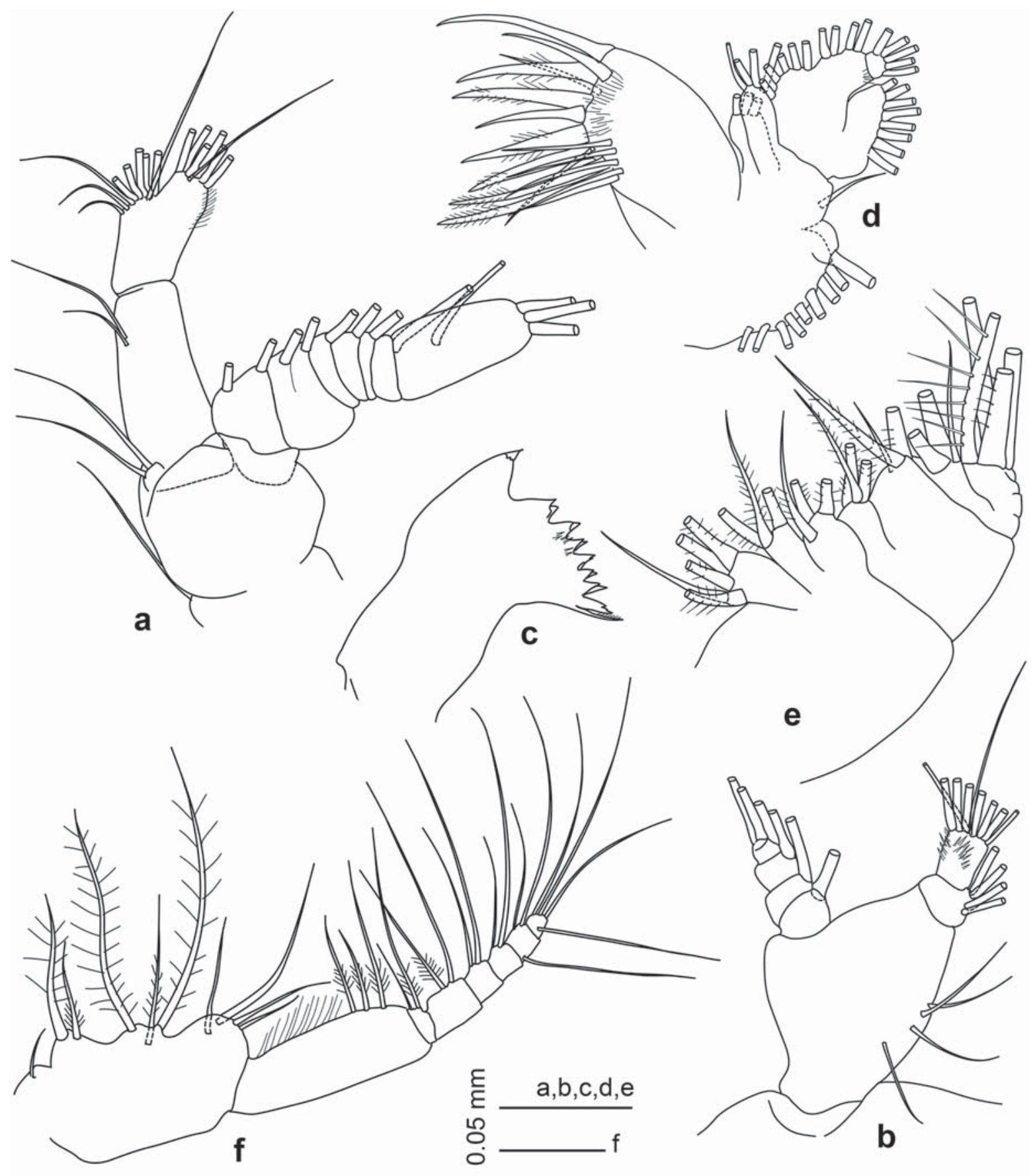

Fig. 2. Centropages ponticus female: $\mathrm{a}$ - antenna; $\mathrm{b}-$ mandibular palp; $\mathrm{c}-$ mandible gnatobase; $\mathrm{d}$ - maxillule; $\mathrm{e}-$ maxilla; $\mathrm{f}-$ maxilliped.

Pис. 2. Centropages ponticus, самка: a — антенна; b — щупик мандибулы; c — жевательный край мандибулы; $\mathrm{d}$ — максиллула; е - максилла; f - максиллипеда.

Maxillule (Fig. 2d): praecoxal arthrite with 15 (9 terminal, 4 posterior and 2 anterior) spines and with fine long setules at the base of the spines; coxal endite with three setae and coxal epipodite with nine setae; basal endites 1 and 2 with four and five setae, respectively; basal exite with one seta; endopod with four lateral and five apical setae, exopod with eight setae.
Maxilla (Fig. 2e) with long, strong and spinous setae: praecoxal endites 1 and 2 with five and three setae, respectively; endites 3 and 4 on coxa with three setae each; basal endite with three setae; endopod with seven setae.

Maxilliped (Fig. 2f): syncoxa with 1, 2, 3, 4 setae; basis with three setae; endopod segment 1 with two 

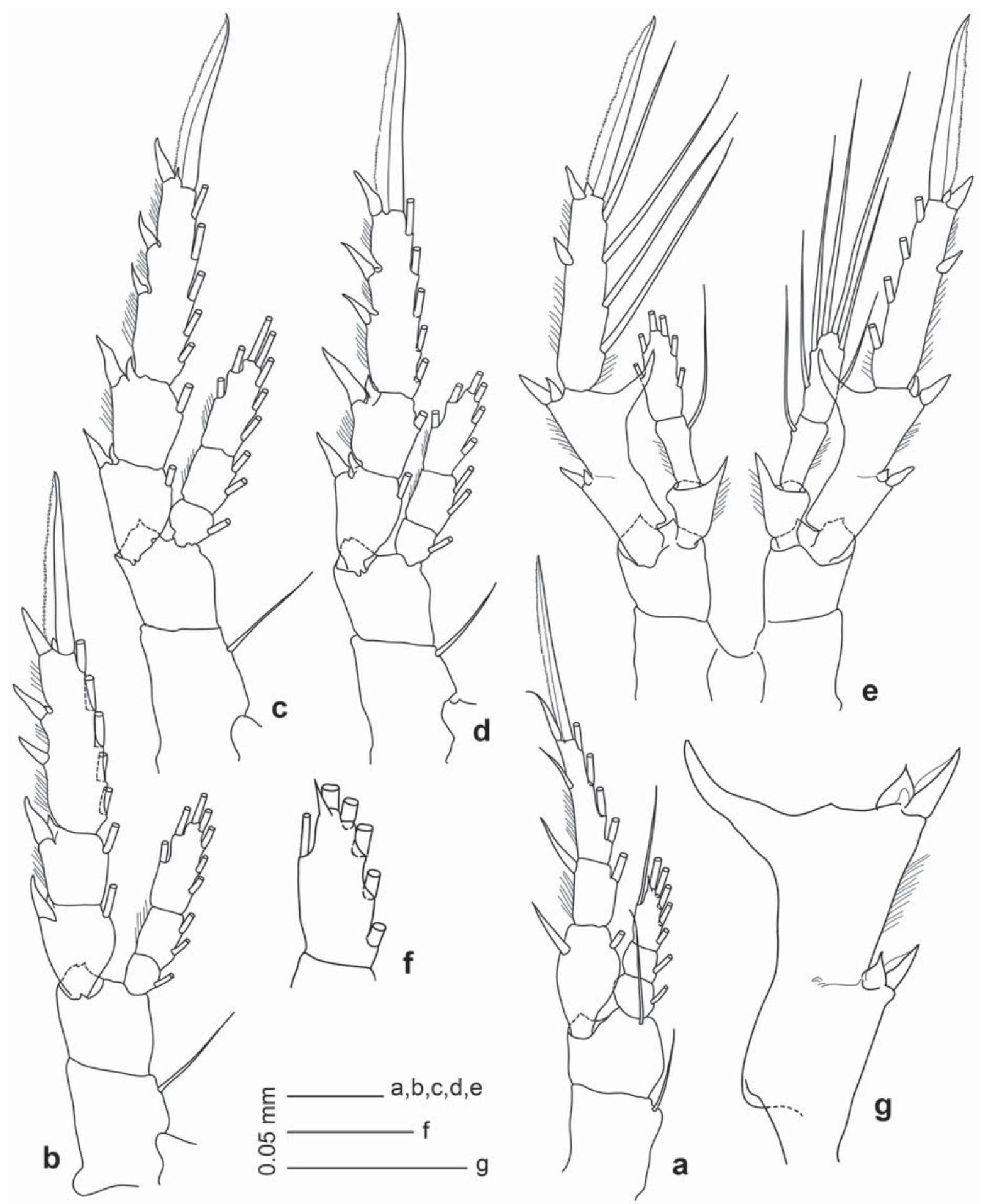

Fig. 3. Centropages ponticus female: a - leg 1, anterior view; $\mathrm{b}-\operatorname{leg} 2$, anterior view; $\mathrm{c}-\operatorname{leg} 3$, anterior view; $\mathrm{d}-\operatorname{leg} 4$, anterior view; e - leg 5, anterior view; f - leg 1, endopod III; g — leg 5, fused exopod segments I-II, anterior view.

Рис. 3. Centropages ponticus, самка: $\mathrm{a}-1$-я нога, вид спереди; $\mathrm{b}-2$-я нога, вид спереди; c - 3-я нога, вид спереди; $\mathrm{d}-4$-я нога, вид спереди; е - 5-я пара ног, вид спереди; f - 3-й членик эндоподита 1-й ноги; g - слившиеся членики I-II экзоподита 5-й ноги, вид спереди.

setae; endopod segments $2-6$ with $2,2,2,2+1,3+1$ setae, respectively.

Legs 1-4 (Figs 3a-d, 7c,d) biramous, with threesegmented endopods and three-segmented exopods.
Spine and seta formulae as in Table 1 (spines are designated by Roman numerals; setae are designated by Arabic numerals). Number of outer spines in exopod 3 and inner setae in endopod 3 of legs 2-4 variable 
Table 1. Spine and seta formulae of swimming legs 1-5 in Centropages ponticus. Таблица 1. Формулы шипов и щетинок плавательных ног 1-5 у Centropages ponticus.

\begin{tabular}{|c|c|c|c|c|}
\hline Leg & Coxa & Basis & Exopod & Endopod \\
\hline P1 & $0-1$ & $0-1$ & I-1; I-1; II, I, 4 & $0-1 ; 0-1 ; 1,2,3$ \\
\hline $\mathrm{P} 2$ & $0-1$ & $0-0$ & I-1; I-1; III/II, I, 5 & $0-1 ; 0-2 ; 2,2,3$ \\
\hline P3 & $0-1$ & $0-0$ & I-1; I-1; III/II, I, 5 & $0-1 ; 0-2 ; 2,2,3$ \\
\hline P4 & $0-1$ & $0-0$ & I-1; I-1; III/II, I, 5 & $0-1 ; 0-2 ; 2,2,2 / 3$ \\
\hline $\mathrm{P} 5$ + & $0-0$ & $0-0$ & II-0; II, I, 4 & $0-0 ; 0-1 ; 2,2,2$ \\
\hline P5 $\sigma^{7}$ left & $0-0$ & $0-0$ & I-0; II, I, 0 & $0-1 ; 0-1 ; 2,2,2$ \\
\hline P5 $\sigma^{7}$ right & $0-0$ & $0-0$ & $\mathrm{I}-0$; I-0; I-I & $0-1 ; 0-1 ; 2,2,2$ \\
\hline
\end{tabular}

Table 2. Variability of spines and setae number in swimming legs 2-4 in Centropages ponticus. Таблица 2. Изменчивость количества шипов и щетинок плавательных ног 2-4 у Centropages ponticus.

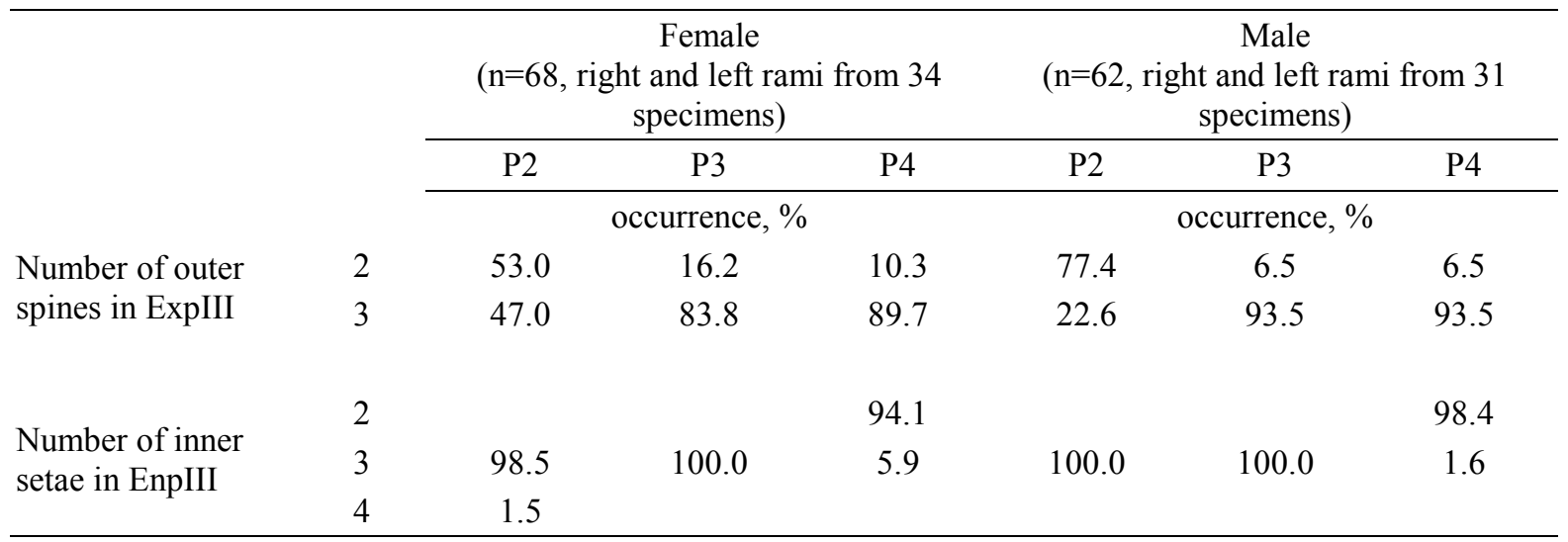

(Table 2). Variability manifests whether in both left and right rami simultaneously or in one ramus only (Fig. 7c). Leg 1 endopod segment 3 distal corner pointed (Fig. 3f).

Leg 5 (Fig. 3e) biramous, symmetrical. Exopod ancestral segments I and II fused, fusion line is faintly visible on anterior surface only and absent in posterior surface (Fig. 7e,f), inner distal corner transformed into strong thick and curved projection (Fig. 3g); endopod three-segmented, segment 1 inner distal corner with large triangular extension reaching the midlenght of endopod segment 2. Spine and seta formula as in Table 1.

Male. Total length $0.92-1.08 \mathrm{~mm}$ (mean $1.01 \mathrm{~mm}$, $\mathrm{n}=32$ ). Body slightly slender than in female, prosome about 2.3 times as long as urosome. Cephalosome and first pedigerous somite, fourth and fifth pedigerous somites separate, the latter with two caudally produced, symmetrical or slightly asymmetrical, with the left one slightly bigger, pointed projections (Fig. 4e,f). Rostrum extends into two thin, ventroposteriorly directed filaments. Urosome of five free somites, genital somite shorter than urosomite II, genital opening on the left side, urosomite $\mathrm{V}$ very small. Caudal rami symmetrical, slightly dilated posteriorly, with six terminal setae and small setules in the inner border; ancestral seta I absent, seta VII inserted immediately anterior to seta
$\mathrm{VI}$; seta $\mathrm{V}$ longest being approximately as long as urosome including caudal rami, seta VII shortest (Fig. $4 \mathrm{a}, \mathrm{e})$.

Left antennule (Fig. 4c) as in female. Right antennule (Fig. 4d,g) geniculated, of 21 free segments, with main geniculation between segments XX and XXI, ancestral segments II-IV, XXI-XXIII, XXIV-XXV fused; armature as follows: I-2s + 1a, II-IV-3s $+1 \mathrm{a}, \mathrm{V}-1 \mathrm{~s}+$ 1a, VI-2s+ 1a, VII-2s+ 1a, VIII-1s + 1a, IX-2s+ 1a, $\mathrm{X}-2 \mathrm{~s}+1 \mathrm{a}$ (distalmost seta modified - shortened and sharply pointed), XI to XVIII-2s + 1a, XIX-1s + 1a, XX-1s + 1a, XXI-XXIII-1s + 1a, XXIV-XXV-2s + $2 \mathrm{~s}$, XXVI-XXVIII-5s + 1a. In segments XII, XIII, $\mathrm{XIV}$, distalmost seta short, in the shape of a spike; segments XVII and XVIII with a lamelliform crest at anterior margin each; segment XIX with a toothed ridge at the proximal anterior margin extending beyond the anterior part of segment XX; segment XX with a smaller, as compared to that of segment XIX, toothed ridge at the proximal anterior margin not reaching the segment's distal end; compound segments XXI-XXIII with a toothed ridge at the proximal anterior margin ending in a pointed and slightly curved lamella at approximately mid-length of the segment (Fig. 4g).

Antenna, mandible, maxillule, maxilla, maxilliped (Fig. 5a-e) well-developed, with segmentation and setal formulae as in female. 


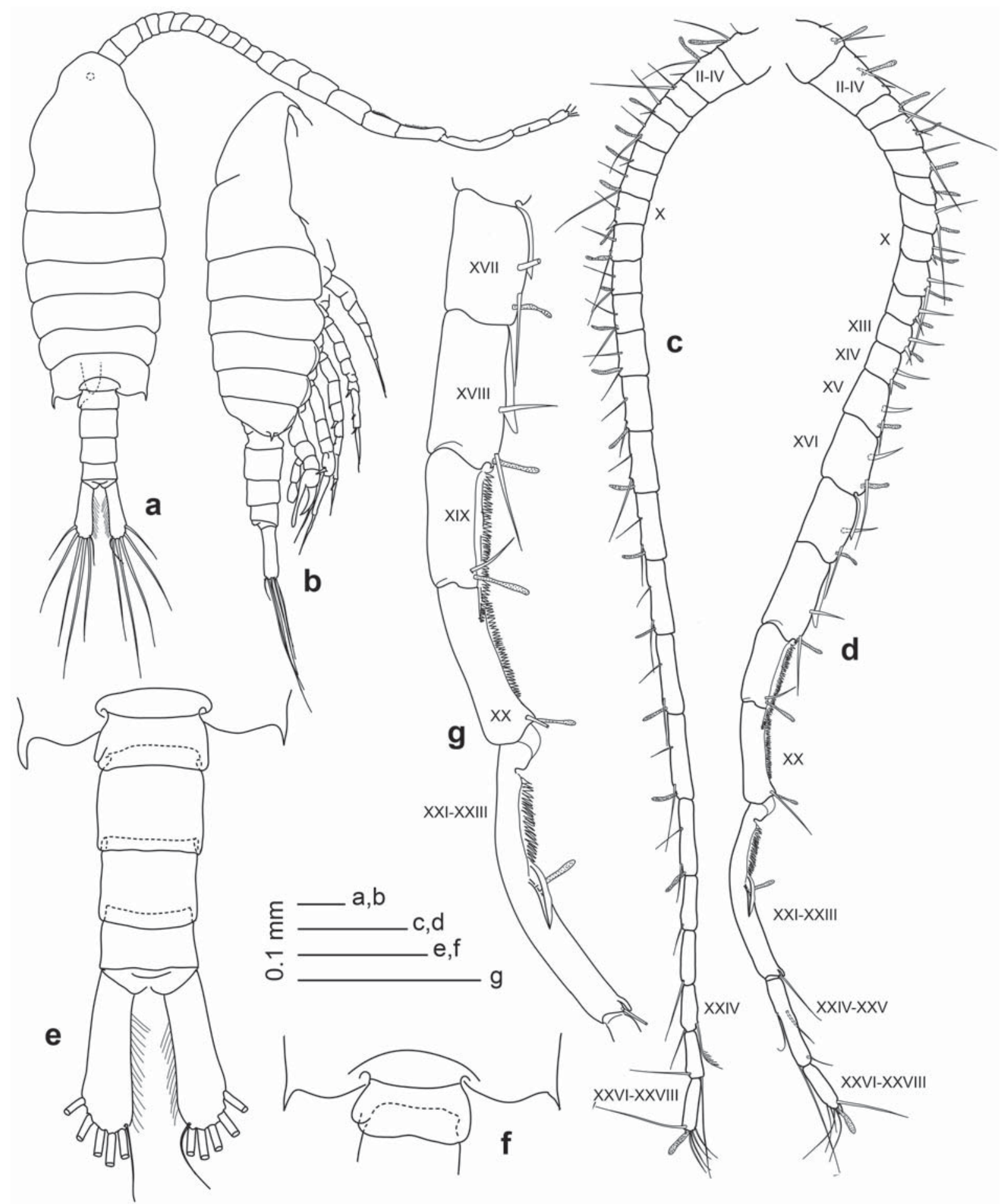

Fig. 4. Centropages ponticus male: a — dorsal view; b - lateral view; c - left antennule; d - right antennule; e - posterolateral corners of 5 th pedigerous somite and urosome, dorsal view; $\mathrm{f}$ - posterolateral corners of 5 th pedigerous somite, a variant, dorsal view; $\mathrm{g}$ right antennule, segments XVII-XXIII.

Рис. 4. Centropages ponticus, самец: a - вид со спинной стороны; b - вид сбоку; с — левая антеннула; $\mathrm{d}$ - правая антеннула; e - заднелатеральные выступы 5-го торакального членика и уросома, вид со спинной стороны; f - заднелатеральные выступы 5го торакального членика, вариант, вид со спинной стороны; g - членики XVII-XXIII правой антеннулы. 


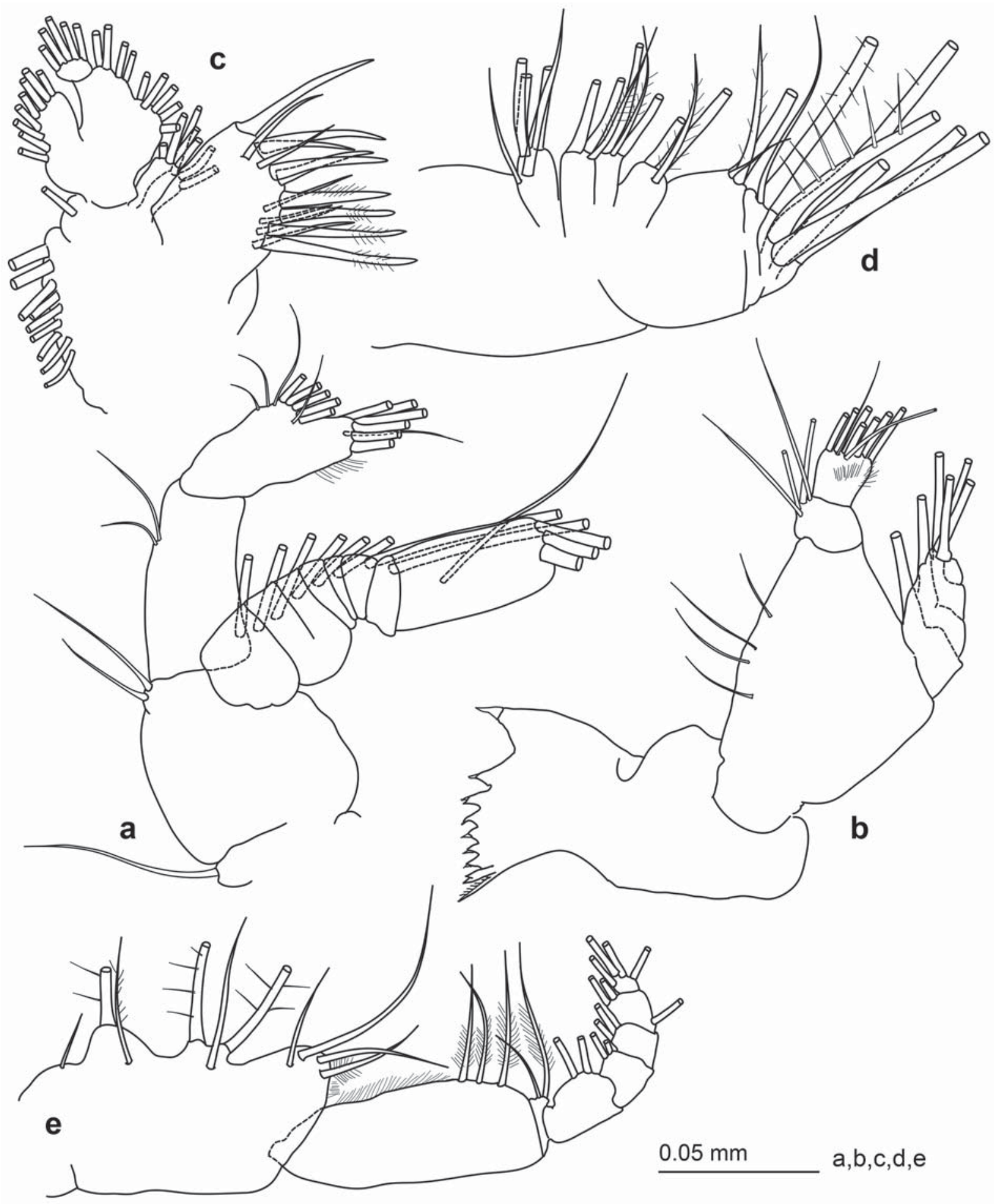

Fig. 5. Centropages ponticus male: $\mathrm{a}$ - antenna; $\mathrm{b}$ - mandible; $\mathrm{c}$ - maxillule; $\mathrm{d}$ - maxilla; $\mathrm{e}$ - maxilliped.

Pис. 5. Centropages ponticus, самец: a — антенна; b - мандибула; c — максиллула; $\mathrm{d}$ - максилла; $\mathrm{e}$ - максиллипеда.

Swimming legs 1-4 (Fig. 6a-d) with segmentation and armature as in female (Table 1), including changeability of the number of outer spines in exopod 3 and inner setae in endopod 3 in legs $2-4$. Leg 4 slightly asymmetrical, with outer spine on right exopod 2 ap- proximately twice longer and directed more laterally than that on left exopod 2.

Leg 5 (Fig. 6 e,f, h,i) biramous, asymmetrical, modified. Left leg: exopod two-segmented with ancestral segments I and II fused, terminal segment with a small 


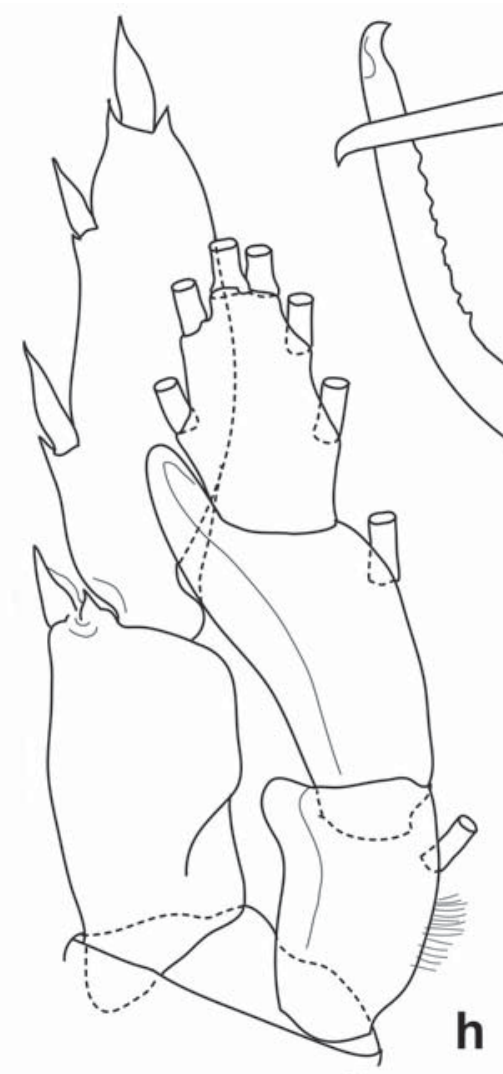

h
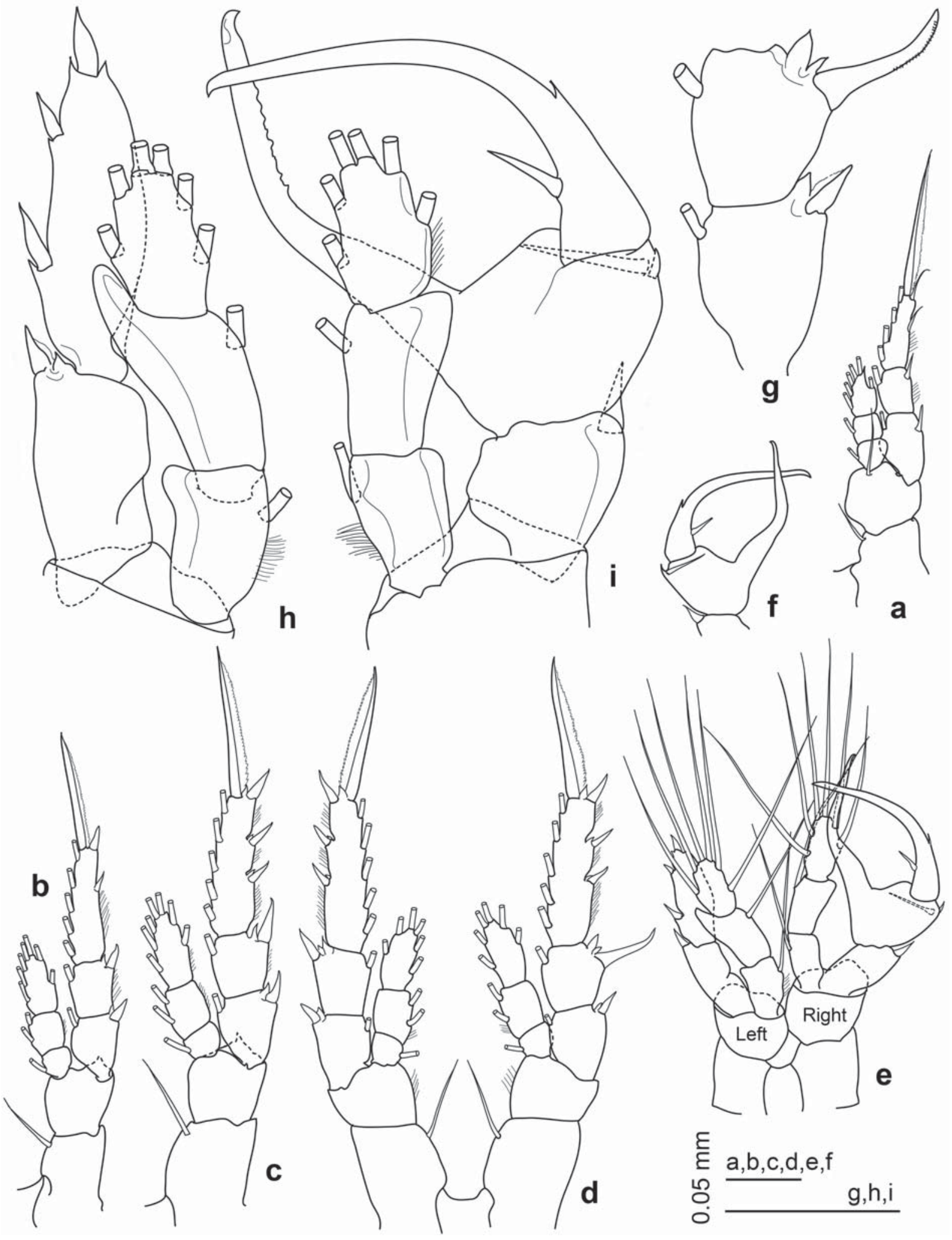

Fig. 6. Centropages ponticus male: a - leg 1, anterior view; b. leg 2, anterior view; $\mathrm{c}-\operatorname{leg} 3$, anterior view; $\mathrm{d}-\operatorname{leg} 4$, anterior view; e - leg 5, anterior view; f - right leg 5, exopod segments II-III, posterior view; g - leg 4 right exopod segments I-II; $\mathrm{h}$ - leg 5, left ramus, anterior view; $\mathrm{i}-\operatorname{leg} 5$, right ramus, anterior view.

Pис. 6. Centropages ponticus, самец: a - 1-я нога, вид спереди; $\mathrm{b}-2$-я нога, вид спереди; c - 3-я нога, вид спереди; $\mathrm{d}-4$-я пара ног, вид спереди; е - 5-я пара ног, вид спереди; f - членики II-III правого экзоподита 5-й ноги, вид сзади; g - членики I-II правого экзоподита 4-й ноги; h - левая ветвь 5-й ноги, вид спереди; i - правая ветвь 5-й ноги, вид спереди. 

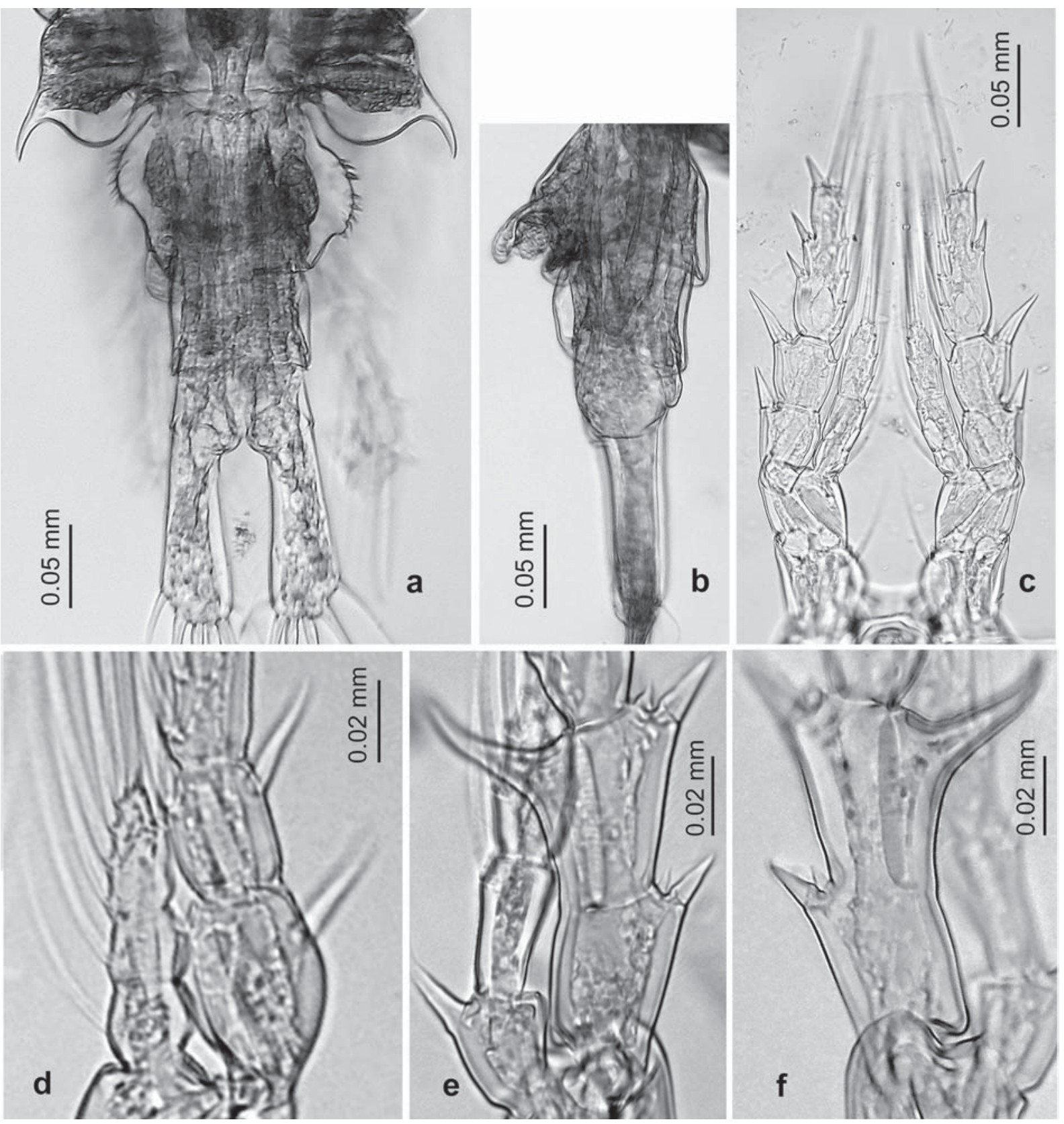

Fig 7. Centropages ponticus female: a - urosome and fifth pedigerous somite, dorsal view; b - urosome, left lateral view; $\mathrm{c}$ - leg 2 demonstrating variability of outer spines in exopod $3 ; \mathrm{d}-$ leg 1 endopod demonstrating presence of only one seta in the second segment; $\mathrm{e}-\operatorname{leg} 5$, fused exopod segments I-II, anterior surface, with fusion line faintly visible; $\mathrm{f}-\operatorname{leg} 5$, fused exopod segments I-II, posterior surface, fusion line absent.

Рис. 7. Centropages ponticus, самка: a - уросома и 5-й торакальный членик, вид со спинной стороны; $\mathrm{b}$ - уросома, вид сбоку слева; с - 2-я пара ног, демонстрирующая вариабельность количества наружных шипов на 3-м членике экзоподита; d эндоподит 1-й ноги, демонстрирующий наличие только одной щетинки на 2-м членике; e - слившиеся членики I-II экзоподита 5й ноги, передняя поверхность, линия слияния едва заметна; f - слившиеся членики I-II экзоподита 5-й ноги, задняя поверхность, линия слияния отсутствует.

terminal spine; endopod three-segmented, segment 1 outer distal corner with a small swelling; segment 2 outer distal corner with a large swelling. Right leg: exopod three-segmented, with two terminal segments forming a chela: segment 2 inner distal corner modi- fied into a claw-like extension, outer distal corner with thin and relatively long spine directed posteriorly; segment 3 elongated and curved, with a medium-sized inner spine and very small outer spine. 
Table 3. Key characters for distinguishing between the species of the hamatus group of the genus Centropages. Таблица 3. Ключевые признаки для различения видов группы hamatus рода Centropages.

\begin{tabular}{|c|c|c|c|c|c|}
\hline Character & C. abdominalis & C. hamatus & C. kroyeri & C. ponticus & C. tenuiremis \\
\hline \multicolumn{6}{|c|}{ FEMALE } \\
\hline $\begin{array}{l}\text { Projections of } \\
\text { the last } \\
\text { thoracic } \\
\text { somite }\end{array}$ & $\begin{array}{l}\text { directed } \\
\text { postero- } \\
\text { aterally; do not } \\
\text { reach midlength } \\
\text { of Gns }\end{array}$ & $\begin{array}{l}\text { directed postero- } \\
\text { aterally; do not } \\
\text { reach midlength } \\
\text { of Gns }\end{array}$ & $\begin{array}{l}\text { directed postero- } \\
\text { aterally; do not } \\
\text { reach midlength } \\
\text { of Gns }\end{array}$ & $\begin{array}{l}\text { directed } \\
\text { postero- } \\
\text { aterally; do } \\
\text { not reach } \\
\text { midlength of } \\
\text { Gns }\end{array}$ & $\begin{array}{l}\text { directed } \\
\text { posteriorly, } \\
\text { extending } \\
\text { beyond posterior } \\
\text { border of Gns }\end{array}$ \\
\hline Leg 5: & symmetrical & symmetrical & symmetrical & symmetrical & asymmetrical \\
\hline $\begin{array}{l}\text { Leg } 5 \\
\text { Exp I-II }\end{array}$ & separate & separate & separate & $\begin{array}{l}\text { fused in both } \\
\text { left and right } \\
\text { rami with } \\
\text { fusion line } \\
\text { partly visible } \\
\text { on anterior } \\
\text { side }\end{array}$ & $\begin{array}{l}\text { fused in right } \\
\text { ramus with } \\
\text { fusion line } \\
\text { partly visible on } \\
\text { anterior side; } \\
\text { separate in left } \\
\text { ramus }\end{array}$ \\
\hline $\begin{array}{l}\text { Leg } 5 \\
\text { Exp II inner } \\
\text { projection }\end{array}$ & $\begin{array}{l}\text { medium-sized, } \\
\text { extends to } \\
\text { midlength of } \\
\text { Exp III }\end{array}$ & $\begin{array}{l}\text { medium-sized, } \\
\text { does not reach } \\
\text { midlength of Exp } \\
\text { III }\end{array}$ & $\begin{array}{l}\text { medium-sized, } \\
\text { does not reach } \\
\text { midlength of Exp } \\
\text { III }\end{array}$ & $\begin{array}{l}\text { medium-sized, } \\
\text { does not reach } \\
\text { midlength of } \\
\text { Exp III }\end{array}$ & $\begin{array}{l}\text { right ramus: } \\
\text { large and } \\
\text { swollen at its } \\
\text { base; } \\
\text { left ramus: } \\
\text { medium-sized, } \\
\text { not swollen at its } \\
\text { base }\end{array}$ \\
\hline $\begin{array}{l}\text { Leg } 5 \\
\text { Enp I inner } \\
\text { distal corner }\end{array}$ & $\begin{array}{l}\text { without } \\
\text { extension }\end{array}$ & without extension & $\begin{array}{l}\text { with large } \\
\text { triangular } \\
\text { extension }\end{array}$ & $\begin{array}{l}\text { with large } \\
\text { triangular } \\
\text { extension }\end{array}$ & $\begin{array}{l}\text { without } \\
\text { extension }\end{array}$ \\
\hline \multicolumn{6}{|c|}{ MALE } \\
\hline $\begin{array}{l}\text { Leg } 4 \text { right } \\
\text { Exp II outer } \\
\text { distal spine }\end{array}$ & $\begin{array}{l}\text { nearly same } \\
\text { size and } \\
\text { direction as in } \\
\text { left Exp II }\end{array}$ & $\begin{array}{l}\text { bigger and } \\
\text { directed more } \\
\text { laterally than that } \\
\text { on left Exp II }\end{array}$ & $\begin{array}{l}\text { bigger and } \\
\text { directed more } \\
\text { laterally than that } \\
\text { on left Exp II }\end{array}$ & $\begin{array}{l}\text { directed more } \\
\text { laterally and } \\
\text { about } 2.5 \\
\text { times as long } \\
\text { as that on left } \\
\text { Exp II }\end{array}$ & $\begin{array}{l}\text { directed } \\
\text { posteriorly, } \\
\text { pubescent, and } \\
\text { about } 2.5 \text { times } \\
\text { as long as that } \\
\text { on left Exp II }\end{array}$ \\
\hline $\begin{array}{l}\text { Leg } 4 \text { right } \\
\text { Exp III lateral } \\
\text { spine } 3\end{array}$ & $\begin{array}{l}\text { about } 0.5 \text { times } \\
\text { as long as } \\
\text { terminal spine }\end{array}$ & $\begin{array}{l}\text { about } 0.3 \text { times as } \\
\text { long as terminal } \\
\text { spine }\end{array}$ & $\mathrm{n} / \mathrm{d}$ & $\begin{array}{l}\text { less than } 0.3 \\
\text { times as long } \\
\text { as terminal } \\
\text { spine }\end{array}$ & $\begin{array}{l}\text { less than } 0.3 \\
\text { times as long as } \\
\text { terminal spine }\end{array}$ \\
\hline $\begin{array}{l}\text { Leg } 5 \text { right } \\
\text { Exp II claw- } \\
\text { like extension }\end{array}$ & $\begin{array}{l}\text { shorter as } \\
\text { compared with } \\
\text { Exp III }\end{array}$ & $\begin{array}{l}\text { shorter as } \\
\text { compared with } \\
\text { Exp III }\end{array}$ & $\begin{array}{l}\text { longer as } \\
\text { compared with } \\
\text { Exp III }\end{array}$ & $\begin{array}{l}\text { shorter as } \\
\text { compared } \\
\text { with Exp III }\end{array}$ & $\begin{array}{l}\text { shorter as } \\
\text { compared with } \\
\text { Exp III }\end{array}$ \\
\hline $\begin{array}{l}\text { Leg } 5 \text { left } \\
\text { Enp II outer } \\
\text { distal corner }\end{array}$ & $\begin{array}{l}\text { with small } \\
\text { swelling }\end{array}$ & without swelling & $\begin{array}{l}\text { with small } \\
\text { swelling }\end{array}$ & $\begin{array}{l}\text { with large } \\
\text { swelling }\end{array}$ & without swelling \\
\hline Sources & $\begin{array}{l}\text { Hirakawa, } \\
\text { 1986; Mori, } \\
\text { 1937; Shen, } \\
\text { Bai, 1956 }\end{array}$ & $\begin{array}{l}\text { Lee, 1972; Sars, } \\
1902\end{array}$ & $\begin{array}{l}\text { Giesbrecht, } 1893 ; \\
\text { Kovalev, } 1967\end{array}$ & $\begin{array}{l}\text { Present study, } \\
\text { the Black Sea } \\
\text { specimens }\end{array}$ & $\begin{array}{l}\text { Original data, } \\
\text { the Arabian Sea } \\
\text { specimens }\end{array}$ \\
\hline
\end{tabular}




\section{Discussion}

Comparison of species within the hamatus group

Vervoort [1964] pointed out the genus Centropages to be "badly in need of a thorough taxonomical revision", and arranged known to that time Centropages species provisionally into five species groups: typicus, furcatus, hamatus, orsinii, and violaceus, with $C$. ponticus referred to the hamatus group along with $C$. abdominalis Sato, 1913; C. alcocki Sewell, 1912; C. hamatus (Lilljeborg, 1853); C. kroyeri Giesbrecht, 1893; C. tenuiremis Thompson et Scott, 1903; and C. trispinosus Sewell, 1914. Subsequently, Ohtsuka et al. [2003, 2005] recognized two other groups: trispinosus and alcocki, thereby removing two corresponding species from the Vervoort's hamatus group. Thus, to date, the hamatus group includes five species (Table 3). $C$. ponticus can be distinguished from the other species of the hamatus group by details of morphology of fifth legs, namely: (i) by having exopod segments I-II fused in both right and left rami in female, and (ii) by having a large swelling on outer distal corner of the left endopod segment II in male. Additionally, from its closest congener, C. kroyeri, C. ponticus is distinguished by relative length of the male fifth leg right exopod segment II claw-like extension: in C. ponticus this element is shorter as compared to exopod segment 3 , whereas in $C$. kroyeri this element is longer as compared to exopod segment 3 .

\section{Morphological variability within $\boldsymbol{C}$. ponticus}

The present study has revealed the occurrence of variability in number of outer spines in exopod 3 of legs 2-4 (two or three spines) in C. ponticus in the Black Sea. Karavaev [1895] also noted that some specimens of $C$. ponticus in his collection had two outer spines in the second leg exopod segment III, considering the segment bearing three spines to be "the norm",

Table 4. Main morphological differences between the specimens of Centropages ponticus from the Black and Mediterranean seas.

Таблица 4. Основные морфологические различия между экземплярами Centropages ponticus из Черного и Средиземного морей.

\begin{tabular}{|c|c|c|c|}
\hline Region & $\begin{array}{l}\text { Sevastopol Bay, } \\
\text { Black Sea, } \\
\text { present study }\end{array}$ & $\begin{array}{l}\text { Cullera Bay, western } \\
\text { Mediterranean } \\
\text { [Soler } \text { et al., 1988] }\end{array}$ & $\begin{array}{l}\text { Saline Lake Mir, Adriatic } \\
\text { Sea [Kršinić, 2017] }\end{array}$ \\
\hline Season of sampling & August 2013 & August* & $\begin{array}{l}\text { November } 1999 \text { - October } \\
2000\end{array}$ \\
\hline \multicolumn{4}{|c|}{ FEMALE } \\
\hline Total length, mm & $\begin{array}{l}1.07-1.22 \\
(\text { mean } 1.15)\end{array}$ & $\begin{array}{l}0.77-0.97 \\
(\text { mean } 0.84)\end{array}$ & $\begin{array}{l}0.74-0.82 \\
(\text { mean } 0.79)\end{array}$ \\
\hline $\begin{array}{l}\text { Th5 postero-lateral } \\
\text { projections }\end{array}$ & symmetrical & $\begin{array}{l}\text { asymmetrical, right } \\
\text { projection bigger }\end{array}$ & $\mathrm{n} / \mathrm{d}$ \\
\hline $\mathrm{Pr} / \mathrm{Ur}$ ratio & $\sim 2.5$ & 2.27 & $\mathrm{n} / \mathrm{d}$ \\
\hline Gns width/height ratio & $\sim 1.4$ & $\sim 1.0$ & $\sim 1.2$ \\
\hline $\begin{array}{l}\text { Spinules on middorsal } \\
\text { surface of Gns }\end{array}$ & absent & present & present \\
\hline Gns dorsal surface & $\begin{array}{l}\text { flat when viewed } \\
\text { laterally }\end{array}$ & $\begin{array}{l}\text { convex when viewed } \\
\text { laterally }\end{array}$ & $\mathrm{n} / \mathrm{d}$ \\
\hline $\begin{array}{l}\text { Number of inner setae in P1 } \\
\text { EnpII }\end{array}$ & 1 & 2 & $\mathrm{n} / \mathrm{d}$ \\
\hline P5 ExpI-II fusion line & $\begin{array}{l}\text { faintly visible on } \\
\text { anterior surface only }\end{array}$ & "not always visible" & absent \\
\hline P5 EnpI internal corner & $\begin{array}{l}\text { with large triangular } \\
\text { extension }\end{array}$ & $\begin{array}{l}\text { without extension, with a } \\
\text { thick and relatively short } \\
\text { seta }\end{array}$ & with a spine-like extension \\
\hline \multicolumn{4}{|c|}{ MALE } \\
\hline Total length, mm & $\begin{array}{l}0.92-1.08 \\
(\text { mean } 1.01)\end{array}$ & $\begin{array}{l}0.66-0.84 \\
(\text { mean } 0.76)\end{array}$ & $\begin{array}{l}0.68-0.80 \\
(\text { mean } 0.76)\end{array}$ \\
\hline $\begin{array}{l}\text { Number of inner setae in P1 } \\
\text { EnpII }\end{array}$ & 1 & 2 & $\mathrm{n} / \mathrm{d}$ \\
\hline
\end{tabular}

* The year of sampling is not indicated in Soler et al., 1988. 
and explaining the variants with two spines by an immature condition of the specimens. Perhaps Karavaev's opinion that three spines are "the norm" was based on the work of Giesbrecht [1893], in which ten different representatives of the genus Centropages were described as having three spines in exopod 3 of legs 2-4. We confirm that specimens with reduced amount of spines and setae in swimming legs in our study were mature females and males. The fact that this kind of variability in $C$. ponticus was recorded earlier, more than 100 years ago [Karavaev, 1895], allows us to conclude that the revealed in the present study variability is one of the morphological characteristics of $C$. ponticus in the Black Sea.

Comparison of the results obtained during the present study with literature data describing $C$. ponticus from the Cullera Bay, western Mediterranean [Soler et al., 1988], and Lake Mir, Adriatic Sea [Kršinić, 2017] has shown that the main morphological features characterizing this species and distinguishing it from its closest congeners (namely, fused exopod segments I-II in leg 5 in female, and details and proportions of leg 5 in male) are similar for the specimens under comparison. However, specimens of $C$. ponticus in each of these three areas have their own distinguishing features, and the Black Sea individuals differ in some morphological details from those of the Mediterranean Sea (Table 4). The most notable differences are in: (i) the total length of both females and males (the Black Sea specimens are about 1.3-1.4 times as long as the Mediterranean Sea ones), (ii) the shape and ornamentation of the genital double-somite (in the Black Sea specimens, dorsal surface of the somite flat, without spinules, whereas in the Mediterranean Sea ones, dorsal surface of the somite convex, with spinules), (iii) the number of setae in the leg 1 endopod segment II ( $C$. ponticus from the Black Sea has one seta in leg 1 endopod segment II whereas specimens from the Cullera Bay have two setae in this segment), (iv) the shape of the female leg 5 endopod segment I internal corner (with large triangular extension in specimens from the Black Sea and Lake Mir, and with no extension in specimens from the Cullera Bay) (Table 4). In the referenced works [Kršinić, 2017; Soler et al., 1988], there are no indications regarding occurrence of variability of the number of outer spines and setae in swimming legs 2-4 in C. ponticus from the Cullera Bay and Lake Mir. The absence of such the indications can both confirm the fact that the Mediterranean specimens of $C$. ponticus do not have this kind of variability, as well as be a consequence of insufficient attention of researchers to these details.

Further investigations of $C$. ponticus in the Mediterranean Sea, including molecular analysis, are needed to obtain accurate information on the intraspecific variability as well as on the degree of relatedness of populations of this species from different regions of the Mediterranean basin.
Acknowledgements. We thank our colleague from the Kovalevsky Institute of Marine Biological Research RAS V.A. Gubanov for his help in collecting the samples. We also owe a considerable debt of gratitude to our reviewers for their constructive comments that helped to improve the paper.

The work was performed within the frames of the IMBR RAS state assignment "Anthropogenic transformation and patterns of formation of biodiversity and bioresources of the Azov-Black Sea basin and other areas of the World Ocean" No. AAAA-A18-118020890074-2.

\section{References}

Coleman C.O. 2003. "Digital inking": how to make perfect line drawings on computers // Organisms Diversity \& Evolution. Vol.14. P.1-14.

Garcia-Rodriguez M. 1985. Contribución al conocimiento de la biología de Centropages ponticus Karavaev (Copepoda, Calanoida) // Boletín del Instituto Español de Oceanografía Vol.2. No.2. P.47-52.

Giesbrecht W. 1893. Systematik und Faunistik der pelagischen Copepoden des Golfes von Neapel und der angrenzenden Meeres-Abschnitte // Fauna und Flora des Golfes von Neapel und der Angrenzenden Meeres-Abschnitte, Herausgegeben von der Zoologischen Station zu Neapel. Bd.19. S.1-831.

Greze V.N., Baldina E.P., Bileva O.K. 1971. [Dynamics of the number and production of the main components of zooplankton in the Black Sea neritic zone] // Greze V.N. (ed.). Plankton yuzhnykh morei. Biologiya Morya, Kiev. T.24. P.12-49 [in Russian].

Gubanova A., Altukhov D., Stefanova K., Arashkevich E., Kamburska L., Prusova I., Svetlichny L., Timofte F., Uysal Z. 2014. Species composition of Black Sea marine planktonic copepods // Journal of Marine Systems. Vol.135. P.44-52.

Gurney R. 1927. Report on the Crustacea: Copepoda and Cladocera of the Plankton // Zoological Results of the Cambridge Expedition to the Suez Canal, 1924. Transactions of the Zoological Society of London. Vol.22. P.139-172.

Hirakawa K. 1986. A new record of the planktonic copepod Centropages abdominalis (Copepoda, Calanoida) from Patagonian waters, southern Chile// Crustaceana. Vol.51. No.3. P.296299.

Huys R., Boxshall G.A. 1991. Copepod Evolution // Ray Society (Publications). London: Ray Society. Vol.159. P.1-468.

Karavaev V. 1895. [Materials for the fauna of pelagic crustaceans of the Black Sea] // Zapiski Kiyevskago Obshchestva Estestvoispytatelei. T.14. Vyp.1. P.117-174 [in Russian].

Kovalev A.V. 1967. [On the systematic position and distribution of Centropages kroyeri var. pontica Karavajev (Crustacea, Copepoda)] // Greze V.N. (ed.). Biologiya i raspredelenie planktona Yuzhnykh morei. Akademiya Nauk SSSR, Okeanograficheskaya Komissiya. Moscow. P.94-99 [in Russian].

Kršinić F. 2017. Taxonomical and ecological characteristics of Centropages ponticus (Copepoda, Calanoida) from the saline Lake Mir (Dugi Otok, Adriatic Sea) // Acta Adriatica. Vol.58. No.3. P.419-428.

Lee C.M. 1972. Structure and function of the spermatophore and its coupling device in the Centropagidae (Copepoda: Calanoida) // Bulletin of Marine Ecology. Vol.8. No.1. P.1-20.

Matishov G.G., Ignatiev S.M., Zagorodnyaya Yu.A., Klimova T.N., Vdodovich I.V., Sayapin V.V., Stepanyan O.V. 2015. [Faunistic diversity and abundance of plankton communities of the Sea of Azov in June 2014] // Vestnik Yuzhnogo nauchnogo tsentra RAN. T.11. No.3. P.81-91 [in Russian].

Mori T. 1937. The Pelagic Copepoda from the Neighbouring Waters of Japan. Tokyo: Yokendo Co. 150 p. [Reprinted in 1964]

Ohtsuka S., McKinnon D., Pinkaew K., Putchakarn S., Chalermwat K. 2003. New record of Centropages brevifurcus (Crustacea: Copepoda: Calanoida) from the Gulf of Thailand and its full redescription // Species Diversity. Vol.8. P.67-78. 
Ohtsuka S., Itoh H., Mizushima T. 2005. A new species of the calanoid copepod genus Centropages (Crustacea) collected from Shimizu Port, middle Japan: Introduced or not? // Plankton Biology and Ecology. Vol.52. No.2. P.92-99.

Papantoniou G., Danielidis D.B., Spyropoulou A., Fragopoulu N. 2015. Spatial and temporal variability of small-sized copepod assemblages in a shallow semi-enclosed embayment (Kalloni Gulf, NE Mediterranean Sea) // Journal of the Marine Biological Association of the United Kingdom. Vol.95. No.2. P.349-360.

Razouls C., De Bovée F., Kouwenberg J., Desreumaux N. 20052019. Diversity and geographic distribution of marine planktonic copepods. Available online at http://copepodes.obsbanyuls.fr/ (accessed April 15, 2019).

Sars G.O. 1902. Copepoda Calanoida, Parts VII \& VIII, Centropagidae, Diaptomidae // An Account of the Crustacea of Norway, with short descriptions and figures of all the species. Bergen Museum. Vol.4. P.73-96.

Shen C.J., Bai S.O. 1956. [The marine Copepoda from the spawning ground of Pneumatophorus japonicus (Houttuyn) off Che- foo, China] // Acta Zoologica Sinica. Vol.8. No.2. P.177-234 [in Chinese with English summary].

Siokou-Frangou I., Shiganova T., Christou E.D., Kamburska L., Gubanova A., Konsulov A., Musaeva E., Skryabin V., Khoroshilov V. 2004. Mesozooplankton communities in the Aegean and Black Seas: a comparative study // Marine Biology. Vol.144. No.6. P.1111-1126.

Soler E., del Rio J.G., Vives F. 1988. Morphological and taxonomical revision of Centropages ponticus Karavaev, 1895 (Copepoda, Calanoida) // Crustaceana. Vol.55. No.2. P.129-146.

Ustun F., Bat L., Mutlu E. 2018. Seasonal variation and taxonomic composition of mesozooplankton in the southern Black Sea (off Sinop) between 2005 and 2009 // Turkish Journal of Zoology. Vol.42. No.5. P.541-556.

Vervoort W. 1964. Notes on two Pacific species of Centropages (Copepoda Calanoida), C. australiensis Fairbridge, 1944, and C. aucklandicus Krämer, 1895 // Crustaceana. Vol.7. No.4. P.293-311.

Responsible editor K.G. Mikhailov 